\title{
Hubungan Status Gizi Dengan Proses Penyembuhan Luka Pada Pasien Post Apendektomi
}

\author{
Andi Siswandi ${ }^{1}$, Mardheni Wulandari ${ }^{2}$, Mizar Erianto ${ }^{3}$, Azahrah Mawaddah ${ }^{4 *}$ \\ ${ }^{1)}$ Departemen Ilmu Bedah Fakultas Kedokteran Universitas Malahayati, andi niiiii@yahoo.com \\ ${ }^{2}$ Departement Anatomi Fakultas Kedokteran Universitas Malahayati, mardheniw@gmail.com \\ ${ }^{3)}$ Departement Ilmu Bedah Fakultas Kedokteran Universitas Malahayati,mizar.erianto@gmail.com \\ ${ }^{4)}$ Fakultas Kedokteran,Universitas Malahayati, mawaddahazahrah@gmail.com
}

\begin{abstract}
ABSTRAK
Apendisitis merupakan bagian dari kasus kegawatan yang sering terjadi pada area abdomen. Apendisitis adalah suatu penyakit prototype yang berlangsung melalui peradangan akibat obstruksi dan iskemia dengan gejala utamanya adalah nyeri yang mencerminkan dari keadaan penyakit. Apendisitis memerlukan tindakan bedah apendektomi untuk mengurangi resiko perforasi. Tindakan bedah pendektomi merupakan salah satu jenis luka yaitu luka insisi. Waktu penyembuhan luka dapat ditentukan dengan membedakan dari jenis luka akut ataupun kronis. Apendektomi yang tidak mengalami infeksi pasca pembedahan termasuk kategori dari luka akut, secara fisiologis luka akut akan sembuh \pm 0-21 hari. Akan tetapi, jika pemberian gizi tidak terpenuhi dengan baik maka akan menghambat proses penyembuhan luka. Faktor yang dapat mempengaruhi proses penyembuhan luka salah satunya adalah status gizi. Penelitian ini bertujuan untuk mengetahui hubungan status gizi dengan proses penyembuhan luka pada pasien post apendektomi di RSUD.Dr.H. Abdoel muluk Bandar Lampung. Penelitian ini merupakan penlitian analitik observasi dengan pendekatan cross sectional. Teknik sampling yang digunakan adalah accidental sampling. Data dianalisis menggunakan uji Chi-square. Dari uji Chi-quare didapatkan hubungan status gizi dengan proses penyembuhan luka yang bermakna $(p<0.05)$ yaitu diperoleh nilai $p=0.004$, dan diperoleh nilai $(O R=10.5)$ dapat dikatakan bahwa status gizi cukup 10.5 kali lebih besar mengalami penyembuhan luka baik jika dibandingkan dengan status gizi kurang. Terdapat hubungan antara status gizi dengan proses penyembuhan luka pada pasien post apendektomi.
\end{abstract}

Kata kunci : Status Gizi, Penyembuhan Luka, Post Apendektomi

\section{ABSTRACT}

Appendicitis is part of the emergency cases that often occur in the abdominal area. Appendicitis is a prototype disease that takes place through inflammation due to obstruction and ischemia with the main symptoms which is pain that reflects the state of the disease. Appendicitis requires surgical appendectomy to reduce the risk of perforation. Apendectomy surgery is one type of wound that is an incision wound. The time of wound healing can be determined by the distinguishing between types of acute or chronic wounds. Appendectomy that does not have a post-surgical infection is categorized as an acute wound, physiologically the acute wound will heal $\pm 0-21$ days. However, if the provision of nutrition is not fulfilled properly it will be almost the wound healing process. One factor that can influence the wound healing process is nutritional status. This study aim to determine the correlation of nutritional status with the wound healing process of post-appendectomy patients in RSUD Dr. H. Abdoel Moeloek, Bandar Lampung. This study used observational analytic with cross sectional approach. The sampling technique used was accidental sampling. The data were analyzed by using Chi-square test. From the Chi-square test found a relationship of nutritional status with a significant wound healing process $(p<0.05)$ which is obtained $p=$ 0.004 , and the value obtained $(O R=10.5)$ can be said that adequate nutritional status is 10.5 times more likely to experience good wound healing when compared to undernourished nutritional status. There is a correlation between nutritional status and wound healing process in post-appendectomy patients.

Keywords: Nutritional Status, Wound Healing,Post Appendectomy

*Korespondensi Author: Azahrah Mawaddah Noviska, Fakultas Kedokteran Universitas Malahayati, mawaddahazahrah@gmail.com,081213215822

\section{PENDAHULUAN}

Apendisitis merupakan bagian dari kasus kegawatan yang sering terjadi pada area abdomen. Apendisitis adalah suatu penyakit prototype yang berlangsung melalui peradangan akibat obstruksi dan iskemia dengan gejala utamanya adalah nyeri yang mencerminkan dari keadaan penyakit. ${ }^{1}$ 
Angka kejadian apendisitis cukup tinggi

di dunia. Berdasarkan World Health Organisation tahun 2010, angka mortalitas akibat apendisitis adalah 21.000 jiwa, di mana populasi laki-laki lebih banyak dibandingkan perempuan. Angka mortalitas appendicitis sekitar 12.000 jiwa pada lakilaki dan sekitar 10.000 jiwa pada perempuan. Di Amerika Serikat terdapat 70.000 kasus appendicitis setiap tahnnya. Kejadian appendicitis di Amerika memiliki insiden 12 kasus per 10.000 anak pertahunya antara kelahiran sampai umur 4 tahun. Kejadian appendicitis meningkat 25 kasus per 10.000 anak pertahunnya antara umur 10-17 tahun di Amerika Serikat. Insidensi apendisitis di Indonesia pun masih menjadi penyokong terbesar untuk pasien operasi setiap tahunnya, sebesar 596.132 orang dengan presentase 3,36\% dilaporkan menderita apendisitis pada tahun 2009, dan meningkat menjadi 621.435 dengan presentase $3,53 \%$ di tahun $2010 .^{2}$ Apendisitis dapat ditemukan pada semua umur. Pada anak kurang dari satu tahun kasusnya sangat jarang dilaporkan dan paling sering terjadi pada usia antara 10 sampai 20 tahun.Kejadian apendisitis pada lelaki dan perempuan umumnya sebanding. Pasien dengan usia yang lebih dari 60 tahun dilaporkan sebanyak 50\% meninggal akibat apendisitis.Insiden apendisitis di Bandar Lampung terbilang cukup tinggi. Berdasarkan data yang diperoleh didapatkan bahwa pasien apendisitis tercatat sebanyak 495 orang. Pasien tersebut terdiri dari pasien rawat jalan sebanyak 306 orang dan yang di rawat inap sebanyak 189 orang pada tahun $2010 .^{3}$

Apendisitis memiliki potensi untuk terjadinya komplikasi parah jika tidak segera diobati, seperti perforasi atau sepsis dan bahkan dapat menyebabkan kematian. Dalam hal ini perlu dilakukan tindakan pembedahan sebagai terapi apendisitis, yang disebut juga apendektomi. ${ }^{4}$ Tindakan bedah apendektomi merupakan salah satu contoh dari jenis luka yaitu luka insisi dimana luka insisi merupakan hilang, rusak, atau terputusnya kontuinuitas sebagian jaringan tubuh yang diakibatkan potongan bersih menggunakan benda tajam yang biasa dibuat oleh ahli bedah untuk prosedur operasi. $^{5}$ Didalam pasca pembedahan, penanganan yang kurang baik rentan akan terjadi infeksi. Penanganan yang baik didalam melakukan manajemen luka akan mengurangi resiko komplikasi, dan apabila terjadi infeksi maka akan menyebabkan masa perawatan yang lebih lama, sehingga biaya perawatan di rumah sakit menjadi lebih tinggi. ${ }^{6}$

Luka adalah terputusnya kontinuitas struktur anatomi jaringan tubuh yang bervariasi mulai dari yang paling sederhana seperti lapisan epitel dari kulit, sampai lapisan yang lebih dalam seperti jaringan subkutis, lemak dan otot bahkan tulang beserta struktur lainnya seperti tendon, pembuluh darah dan syaraf, sebagai akibat dari trauma atau ruda paksa atau trauma dari luar. ${ }^{7}$ Waktu penyembuhan luka dapat ditentukan dengan membedakan dari jenis luka akut ataupun kronis. Apendektomi yang tidak mengalami infeksi pasca pembedahan termasuk kategori dari luka akut, secara fisiologis luka akut akan sembuh $\pm 0-21$ hari. Akan tetapi, jika pemberian nutrisi tidak terpenuhi dengan baik maka akan menghambat proses penyembuhan luka. $^{8}$

Faktor yang dapat mempengaruhi proses penyembuhan luka salah satunya adalah status gizi. Penilaian luka didasarkan pada pemeriksaan klinis pada pasien dan dinilai pada fase inflamasi dan fase proliferasi. Pada fase inflamasi terjadi kemerahan, suhu terasa hangat disekitar luka, rasa nyeri,dan pembengkakan. Pada fase proliferasi luka mulai merapat, tegangan pada luka mulai berkurang, oedema berkurang, warna kemerahan pada luka berkurang, suhu teraba normal di sekitar luka,nyeri pada luka berkurang dan luka terasa gatal. Luka dikatakan sembuh ttertunda bila terdapat eksudat dan tanda-tanda infeksi, terdapat diskointuinitas jaringan,luka berbau, luka basah, dan jahitan yang masih terbuka. ${ }^{5}$

Menurut Rusjiyanto yang tarkait dengan proses penyembuhan luka pasca operasi, salah satunya adalah penelitian tentang "Pengaruh Pemberian Suplemen Seng (Zn) Dan Vitamin C Terhadap Kecepatan Penyembuhan Luka Pasca Bedah di Rumah Sakit Umum Daerah Kabupaten Sukoharjo" dari data yang diperoleh 
lebih dari 50\% pasien bedah yang dirawat lebih dari seminggu menderita anemia, mal nutrisi ataupun defisiensi vitamin. Perbaikan status gizi pada pasien dengan kasus pembedahan sangatlah penting untuk mempercepat proses penyembuhan luka operasi dan penyakit dasarnya sendiri. Salah satu faktor penyebab adanya permasalahan tersebut diantaranya karena pasien-pasien bedah di rumah sakit merupakan pasien yang rentan mal nutrisi, oleh karena itu pemberian nutrisi yang tepat pada pasien rawat inap di rumah sakit akan meningkatkan outcome klinik menuju kesembuhan. ${ }^{9}$

Berdasarkan penelitian tentang "faktorfaktor yang berhubungan dengan penyembuhan luka post operasi laparotomi di ruang rawat inap RSUD Tugurejo Semarang" yang dilakukan oleh Nurwahyuningati, dari hasil analisis menunjukan adanya hubungan antara status gizi dengan penyembuhan luka dimana pada seorang dengan status gizi kurang dan mengalami luka sembuh lama sebanyak $78,6 \%$ lebih besar dibandingkan dengan status gizi baik dan mengalami luka sembuh lama. ${ }^{10}$

Pada beberapa penelitian yang terkait dengan proses penyembuhan luka pasca operasi, salah satunya adalah Penelitian tentang "Analisis faktor-faktor yang mempengaruhi proses penyembuhan luka post apendektomi di RSUD Prof. Dr. Aloei saboe Kota Gorontalo" yang dilakukan oleh Yusuf, dari hasil analisis menunjukan adanya hubungan bermakna antara status nutrisi dengan proses penyembuhan luka post operasi apendektomi dimana orang dengan nutrisi kurang yang mengalami luka tidak sembuh sebanyak $88.2 \%$ lebih besar dibandingkan orang yang mengalami luka sembuh dengan nutrisi kurang sebanyak 14.3\% artinya pasien dengan nutrisi yang kurang mempunyai kemungkinan untuk mengalami luka tidak sembuh dibandingkan pasien dengan nutrisi yang baik. ${ }^{11}$

Dari berbagai uraian di atas, maka penulis tertarik untuk melakukan penelitian tentang "Hubungan Status Gizi Dengan Proses Penyembuhan Luka Pada Pasien Post Apendektomi di RSUD. Dr. H. Abdoel muluk
Bandar Lampung”. Permasalahan dalam penelitian ini adalah Apakah ada hubungan antara status gizi dengan proses penyembuhan luka pada pasien post apendektomi di RSUD. Dr. H. Abdoel muluk Bandar Lampung. Tujuan penelitian ini adalah Mengetahui hubungan status gizi dengan proses penyembuhan luka pada pasien post apendektomi di RSUD. Dr. H. Abdoel muluk Bandar Lampung.

\section{METODE}

Jenis penelitian adalah penelitian dalam bentuk analitik observasi yaitu penelitian yang didasarkan pada pengamatan sekelompok tertentu dalam jangka waktu tertentu. Rancangan dalam penelitian ini adalah dengan menggunakan rancangan cross sectional. Penelitian ini di lakukan di RSUD Dr. Abdul Moeloek Bandar Lampung pada bulan Januari Februari 2020. Sampel yang dipakai dalam penelitian ini diambil berdasarkan kriteria inklusi dan eklusi yaitu, kriteria inklusinya adalah pasien yang di diagnosis apendisitis akut dan akan dilakukan open apendiktomi, pasien yang bersedia menjadi responden dan kriteria eklusinya adalah pasien yang melakukan post apendektomi perlaparotomi, pasien dengan komplikasi, pasien post open apendektomi dengan penyakit penyerta seperti, diabetes melitus, gangguan pembekuan darah.

Cara pengambilan sampel pada penelitian ini menggunakan Teknik accidental sampling. Metode pengumpulan data yang digunakan dalam penelitian ini adalah pengumpulan data primer, yang artinya data diperoleh secara langsung pada saat penelitian dengan lembar observasi untuk variabel dependen proses penyembuhan luka post apendiktomi, yaitu dengan cara peneliti yang mengobservasi proses penyembuhan luka yang dimulai pada hari ke 3 post operasi apendiktomi di RSUD Dr. H. Abdoel Muluk lembar observasi yang dibuat sendiri oleh peneliti berdasarkan kriteria penyembuhan luka menurut Smeltzer dan Bare. Dan data sekunder diperoleh dari rekam medis untuk melihat IMT.

Terdapat 3 tahapan dalam proses pelaksana, yaitu 1).Tahap pertama: peneliti terlebih dahulu melihat data pasien untuk 
menghitung IMT, 2).Tahap kedua: peneliti mengisi lembar observasi luka pada saat pasien ganti perban hari ke-3, 3).Tahap ketiga: Peneliti melakukan analisis data univariat Analisis yang bersifat univariat untuk melihat distribusi frekuensi dari seluruh faktor yang terdapat dalam variabel masing-masing, baik variabel bebas maupun variabel terikat, untuk mendapatkan gambaran jawaban responden dan menjelaskan karakteristik masing-masing variabel dan analisis bivariat digunakan untuk melihat hubungan antara variabel independent dengan variabel dependen. Pada penelitian ini peneliti menggunakan uji bivariat yaitu Uji ChiSquare.

\section{HASIL DAN PEMBAHASAN}

Responden dalam penelitian ini adalah pasien post operasi apendektomi di RSUD Dr. H. Abdul Moeloek Bandar Lampung sejak Januari sampai Februari 2020. Responden yang dipakai dalam penelitian ini berjumlah 18 orang diambil berdasarkan teknik accidental sampling.

Tabel 1 menunjukan distribusi frekuensi usia pada pasien post apendektomi di RSUD Dr. H.Abdul Moeloek Bandar Lampung berjumlah 30 pasien $(100 \%)$ dengan kasus terbanyak pada pasien berusia $<30$ tahun berjumlah 20 orang (666.7) $>30$ tahun berjumlah 10 orang $(33.3 \%)$.

Tabel 1. Distribusi Frekuensi Usia Pasien

Post Apendektomi di RSUD Dr. H. Abdul

Moeloek Bandar Lampung

\begin{tabular}{ccc}
\hline Usia & Frekuensi & $\begin{array}{c}\text { Persentase } \\
(\%)\end{array}$ \\
\hline$<30$ tahun & 20 & 66.7 \\
$>30$ tahun & 10 & 33.3 \\
\hline Jumlah & 30 & 100
\end{tabular}

Tabel 2. Distribusi Frekuensi Jenis Kelamin Pasien Post Apendektomi di RSUD Dr. H. Abdul Moeloek Bandar Lampung

\begin{tabular}{lcc}
\hline $\begin{array}{c}\text { Jenis } \\
\text { Kelamin }\end{array}$ & Frekuensi & Persentase(\%) \\
\hline Laki-Laki & 19 & 63.3 \\
Perempuan & 11 & 36.7 \\
\hline Jumlah & 30 & 100
\end{tabular}

Tabel 2. Memperlihatkan distribusi frekuensi responden berdasarkan jenis kelamin pada pasien post apendektomi dengan kasus terbanyak pada pasien laki-laki berjumlah 19 orang $(63.3 \%)$ dan terendah pada pasien perempuan berjumlah 11 orang $(36.7 \%)$.

Tabel 3. Hubungan Status Gizi dengan Proses Penyembuhan Luka Pada Pasien Post Apendektomi di RSUD Dr. H. Abdul Moeloek Bandar Lampung

\begin{tabular}{|c|c|c|c|c|c|c|c|c|}
\hline \multirow{3}{*}{$\begin{array}{c}\text { Status } \\
\text { Gizi }\end{array}$} & \multicolumn{4}{|c|}{ Penyembuhan Luka } & \multirow{2}{*}{\multicolumn{2}{|c|}{ Total }} & \multirow{3}{*}{$\begin{array}{c}\mathrm{P}- \\
\text { value }\end{array}$} & \multirow{3}{*}{$\begin{array}{c}\text { PR } \\
(95 \% \\
\mathrm{CI}) \\
\end{array}$} \\
\hline & \multicolumn{2}{|c|}{ Kurang baik } & \multicolumn{2}{|c|}{ Baik } & & & & \\
\hline & $\mathrm{N}$ & $\%$ & $\mathrm{~N}$ & $\%$ & $\mathrm{~N}$ & $\%$ & & \\
\hline $\begin{array}{c}\text { Gizi } \\
\text { kurang }\end{array}$ & 9 & 75 & 3 & 25 & 12 & 100 & \multirow{2}{*}{0,004} & $\begin{array}{c}10.5 \\
(1.889\end{array}$ \\
\hline $\begin{array}{c}\text { Gizi } \\
\text { Lebih }\end{array}$ & 4 & 22.2 & 14 & 77.8 & 18 & 100 & & $\begin{array}{c}- \\
58.359)\end{array}$ \\
\hline Total & 13 & 43.3 & 17 & 56.7 & 30 & 100 & & \\
\hline
\end{tabular}

Tabel 3 diketahui bahwa dari hasil penelitian didapatkan dari 12 responden dengan status gizi kurang ada sebanyak 9 responden (75\%) yang mengalami penyembuhan luka kurang baik, sedangkan dari 18 responden dengan status gizi lebih ada sebanyak 14 responden $(77.8 \%)$ yang mengalami penyembuhan luka baik.
Berdasarkan uji statistik diperoleh nilai $\mathrm{p}$ value $=0 . .004(\mathrm{PR}=10.5)$ dan $(95 \% \mathrm{CI}=$ 1.889-58.359), maka dapat disimpulkan bahwa ada hubungan bermakna antara status gizi dengan proses penyembuhan luka pada pasien post operasi apendektomi (Ha diterima dan $\mathrm{H} 0$ ditolak). Dari nilai PR dengan pendekatan odds ratio ( $\mathrm{PR}=$ Prevalensi Ratio) dapat dikatakan 
bahwa status gizi lebih berisiko 10.5 kali lebih besar mengalami penyembuhan luka baik jika dibandingkan dengan status gizi kurang.

Dari hasil analisis menunjukan bahwa terdapat hubungan status gizi dengan proses penyembuhan luka. Dari perhitungan yang terlampir, didapatkan nilai p-value sebesar 0.004 yang artinya $p$-value $<0.05$ maka $\mathrm{H} 0$ ditolak dan Ha diterima yang berarti terdapat hubungan antar kedua variabel. Hal tersebut sesuai dengan teori yang menyebutkan, apabila status gizi pasien baik makan penyembuhan luka juga akan baik.

Diketahui bahwa hasil analisis hubungan antara status gizi dengan proses penyembuhan luka pada pasien post apendektomi diperoleh dari 12 responden dengan status gizi kurang ada sebanyak 9 responden (75\%) yang mengalami penyembuhan luka kurang baik, sedangkan dari 18 responden dengan status gizi lebih ada sebanyak 14 responden (77.8\%) yang mengalami penyembuhan luka baik. Dari hasil analisis diperoleh nilai PR dengan pendekatan odds ratio $(\mathrm{PR}=$ Prevalensi Ratio) memiliki kecenderungan berisiko 10.5 kali lebih besar status gizi lebih mengalami penyembuhan luka baik jika dibandingkan dengan status gizi kurang.

Status gizi merupakan salah satu faktor yang berpengaruh langsung terhadap keadaan kesehatan seseorang yang dipengaruhi oleh konsumsi makanan yang tidak sesuai dengan kebutuhan tubuh baik kuantitas maupun kualitasnya. Apabila zat gizi yang dibutuhkan tidak cukup akan mempengaruhi proses penyembuhan luka, menaikkan kepekaan terhadap infeksi, menyumbang peningkatan insiden komplikasi dan akan mengakibatkan perawatan yang lebih lama. Status gizi kurang, terjadi bila tubuh mengalami kekurangan satu atau lebih zat-zat gizi esensial secara terus menerus dalam waktu yang lama. Kekurangan gizi terutama protein sangat berpengaruh terhadap proses penyembuhan luka. Protein diperlukan untuk penyembuhan luka dan untuk membangun kembali berbagai jaringan tubuh yang mengalami perubahan setelah menjalani tindakan pembedahan. Sumber protein dapat diperoleh dari protein hewani dan protein nabati. Protein hewani merupakan protein sempurna yaitu protein yang mengandung asam amino esensial lengkap. Sedangkan protein nabati merupakan jenis protein tidak sempurna karena tidak mengandung asam amino esensial atau kandungan asam amino esensialnya sangat rendah sehingga dinilai tidak dapat menjamin berbagai keperluan pertumbuhan dan mempertahankan kehidupan berbagai jaringan pada tubuh. Protein hewani antara lain terdapat pada telur, daging, ikan, udang, susu, dan keju. Sedangkan protein nabati banyak terkandung dalam tahu, tempe, kacang-kacangan, jagung dan lain-lain. ${ }^{13}$ Status gizi orang dewasa dapat ditentukan dengan Indeks Massa Tubuh (IMT) atau Body Mass Index (BMI), khususnya yang berkaitan dengan kekurangan dan kelebihan berat badan. Masalah kekurangan dan kelebihan gizi pada dewasa (di atas 18 tahun) merupakan masa penting, karena selain mempunyai resiko penyakit tertentu, juga dapat mempengaruhi produktifitas kerjanya. IMT dipercayai dapat menjadi indikator atau menggambarkan kadar adipositas dalam tubuh seseorang. Lemak memiliki peran penting dalam struktur dan fungsi membran sel. Peran asam lemak dalam penyembuhan luka masiih belum begitu dimengerti, tetapi diketahui bahwa lemak berperan untuk sintesis sel tubuh. Kekurangan lemak tubuh dapat menunda penyembuhan luka akan tetapi pasien yang gemuk atau kelebihan lemak dalam tubuh/jaringan dapat meningkatkan resiko infeksi pada luka karena suplai darah jaringan adiposa tidak adekuat. ${ }^{10}$

Secara fisiologis pada pasien post operasi terjadi peningkatan ekspenditur untuk energi dan perbaikan, meningkatnya kebutuhan untuk homeostasis, pemulihan. Hasil positif pembedahan sangat tergantung pada mekanisme imun yang adekuat dan penyembuhan luka. Keduanya bergantung dari peningkatan sintesis protein baru, yang secara signifikan membatasi keseimbangan nitrogen dan keseimbangan energi. Semi-starvasi akan terjadi dalam beberapa hari bukan beberapa minggu, jika intake tidak memenuhi kebutuhan, khususnya protein dan energi. ${ }^{12}$ 
Malnutrisi dapat mempengaruhi beberapa area dari proses penyembuhan. Kekurangan protein menurunkan sintesa dari kolagendan leukosit. Ketika luka terinfeksi, respon inflamasi berlangsung lama dan penyembuhan luka terlambat. Pada orang-orang yang gemuk penyembuhan luka lambat karena suplai darah jaringan adipose tidak adekuat dan jaringan lemak lebih sulit menyatu, dan lama untuk sembuh. ${ }^{11}$ Jaringan lemak kekurangan persediaan darah yang adekuat untuk menahan infeksi bakteri dan mengirimkan nutrisi dan elemen-elemen seluler untuk penyembuhan. Apabila jaringan yang rusak tersebut tidak segera mendapatkan nutrisi yang dibutuhkan maka proses penyembuhan luka juga akan terhambat. ${ }^{9}$

Hal ini sesuai dengan teori Dilla yang menyatakan bahwa salah satu faktor yang mempengaruhi penyembuhan luka adalah malnutrisi dan obesitas. ${ }^{14}$ Juga sesuai dengan hasil penelitian Nurwahyuningati yang menunjukan adanya hubungan yang signifikan antara status gizi dengan penyembuhan luka, dimana pada status gizi kurang sebanyak 78,6\% yang mengalami penyembuhan luka lama dibandingkan dengan yang berstatus gizi lebih. ${ }^{15}$

\section{KESIMPULAN DAN SARAN}

Gambaran Distribusi Responden Pada Pasien Post Apendektomi di RSUD. Dr. H. Abdul Moeloek Bandar Lampung. Diketahui dari seluruh sampel, banyak ditemukan pada pasien post apendektomi usia $<30$ tahun sebanyak 20 sampel (66.7\%). Dan pada jenis Kelamin banyak ditemukan pada pasien post apendektomi jenis kelamin laki-laki sebanyak 19 sampel (63.3\%). Dapat disimpulkan bahwa ada hubungan antara status gizi dengan proses penyembuhan luka pada pasien post apendektomi di RSUD. Dr. H. Abdul Moeloek Bandar Lampung, Status gizi lebih 10.5 kali lebih besar mengalami penyembuhan luka baik jika dibandingkan dengan status gizi kurang.

Saran untuk peneliti selanjutnya diperlukan penelitian multicenter dalam jumlah populasi yang lebih luas dengan tempat penelitian yang berbeda dan penelitian primer yang dapat menentukan faktor-faktor yang mempengaruhi proses penyembuhan luka post operasi apendektomi yang belum dapat diteliti pada kesempatan kali ini.

\section{UCAPAN TERIMAKASIH}

Peneliti mengucapkan terima kasih kepada semua pihak yang berperan dalam pelaksanaan penelitian ini, terutama kepada RSUD Dr. H. Abdul Moeloek yang telah mendukung pelaksanaan penelitian.

\section{REFERENSI}

1. Zamzahar, Zarni, Eliza Anas. Pengaruh Teknik Relaksasi Nafas Dalam dan Masase Terhadap Penurunan Skala Nyeri Pasien Pasca Apendiktomi di Ruang Bedah RSUD Dr. M. Zein Painan. NERS Jurnal Keperawatan. 2012;8(2):138-146.

2. Depkes,RI. Pedoman praktis memantau status gizi orang dewasa. Jakarta Depkes RI. 2011;110.

3. Ceresoli M, Zucchi A, Allievi N, et al. Acute appendicitis: Epidemiology, treatment and outcomes- analysis of 16544 consecutive cases. World J Gastrointest Surg. 2016;8(10): 693-699. https://doi:10.4240/wjgs.v8.i10.

4. Akbar MF, Mutmainah N . Evaluasi Penggunaan Antibiotik Profilaksis Operasi Apendisitis Pada Pasien Dewasa Di RSUD Dr. Moewardi Tahun 2017 (Skripsi). Surakarta:Universitas Muhamadiyah Surakarta ;2017.

5. Sugiartanti MF, Oesman D,Elfiah U. Pengaruh Kadar Albumin Serum terhadap Penyembuhan Luka pada Pasien Pascaoperasi Laparotomi dan Lumbotomi di RSD dr. Soebandi Jember. Jurnal Pustaka Kesehatan. 2018;6(3):383-386.

6. Puspitasari HA,Basirun, Sumarsih T. Faktorfaktor yang mempengaruhi Penyembuhan Luka Post Operasi Sectio Caesarea (SC).Jurnal Ilmiah Kesehatan Keperawatan.2011; 7(1).

7. Primadina N, Basori A, Perdanakusuma DS. Proses Penyembuhan Luka Ditinjau Dari Aspek Mekanisme Seluler Dan Molekuler. Qanun Medika-Medical Journal Faculty of Medicine Muhammadiyah Surabaya. 2019;3(1):31-43.

8. Hasibuan MTD. Hubungan Status Nutrisi dengan Waktu Penyembuhan Luka pada Pasien Post Apendiktomi di Rumah Sakit Kota Medan. Jurnal Ilmiah Keperawatan Imelda. 2018;4(1):427-430. 
9. Rusjianto. Pengaruh Pemberian Suplemen Seng (Zn) Dan Vitamin C Terhadap Kecepatan Penyembuhan Luka Pasca Bedah di Rumah Sakit Umum Daerah Kabupaten Sukoharjo. Jurnal Kedokteran Indonesia. 2009;1(1).

10. Nurwahyuninati D, Aini F, Siswanto Y. FaktorFaktor Yang Berhubungan Dengan Penyembuhan Luka Post Operasi Laparotomi di Ruang Rawat Inap RSUD Tugurejo Semarang (Skripsi). Semarang:STIKES Ngudi Waluyo Ungaran;2016.

11. Yusuf NA. Analisis Faktor-Faktor Yang Mempengaruhi Proses Penyembuhan Luka Post Appendectomy Di Rsud Prof. Dr. Aloei Saboe Kota Gorontalo (Skripsi). Gorontalo: Universitas Negeri Gorontalo;2014.

12. Elisa. Hubungan Antara Status Gizi Terhadap Proses Penyembuhan Luka Post Section Caesar Di Ruang Dewi Kunti RSUD Kota Semarang. Jurnal Keperawatan Maternitas. 2014;1(2):2026.

13. Said S, Taslim NA, Bahar B. Gizi dan Penyembuhan Luka. Jakarta: EGC;2013.

14. Elnovriza D, Bachtiar H, Yenrina. Faktor-faktor Yang Berrhubungan dengan Tingkat Asupan Zat Gizi Mahasiswa Universitas Andalas yang berdomisili di Asrama Mahasiswa (Skripsi).Padang: Universitas Andalas;2010.

15. Hartiningtyaswati S. Hubungan Perilaku Pantang Makan dengan Lama Penyembuhan Luka Perineum pada Ibu Nifas di Kecamatan Srengat Kabupaten Blitar (Skripsi). Surakarta: Universitas Sebelas Maret;2010. 